\title{
The Use of Ultrasonography for the Guidance of Epidural Analgesia in Obstetric Anesthesia
}

${ }^{1}$ Hana Teissler, ${ }^{2}$ Claudia Lozano, ${ }^{3}$ Sanja Kupesic Plavsic

\begin{abstract}
This review article describes the development of the use of ultrasound guidance for neuraxial blocks in obstetric anesthesia. Current evidence of the clinical utility and application, basic lumbar spine sonoanatomy and practical clinical approach of the ultrasound-guided technique for neuraxial blocks are presented and discussed. Suggested curriculum is intended to prepare anesthesiology residents for application of ultrasound guidance in epidural analgesia and obstetric anesthesia.
\end{abstract}

Keywords: Ultrasound for epidural analgesia, Ultrasound guidance for obstetric analgesia and anesthesia, Ultrasound for neuraxial blocks, Teaching of ultrasound imaging and technical skills in anesthesiology, Role of ultrasound in regional anesthesia.

How to cite this article: Teissler H, Lozano C, Kupesic Plavsic S. The Use of Ultrasonography for the Guidance of Epidural Analgesia in Obstetric Anesthesia. Donald School J Ultrasound Obstet Gynecol 2014;8(1):44-51.

\section{Source of support: Nil}

Conflict of interest: None

\section{INTRODUCTION}

Ultrasound skills for the guidance of regional anesthesia in both acute pain management and obstetric anesthesiology are used globally in modern practice of anesthesiology. Ultrasound skills are currently standard of practice for central venous access, highly recommended by the guidelines of both American Society of Regional anesthesia (ASRA), European Society of Regional Anesthesia (ESRA) for peripheral nerve blocks, as well as recommended guidance for obstetrics analgesia and anesthesia by the National Institute of Health and Clinical Excellence (NICE) of the

${ }^{1}$ Assistant Professor, ${ }^{2}$ Clinical Research Coordinator, ${ }^{3}$ Professor and Assistant Dean for Faculty Development, Clinical Professor of Radiology

${ }^{1,2}$ Department of Anesthesiology, Paul L Foster School of Medicine, Texas Tech University at EI Paso, Texas, USA

${ }^{3}$ Department of Obstetrics and Gynecology, Paul L Foster School of Medicine, Texas Tech University at EI Paso, Texas, USA

Corresponding Author: Hana Teissler, Assistant Professor Associate Residency Program Director, Department of Anesthesiology, Paul L Foster School of Medicine, Texas Tech University Health Science Center, 4800 Alberta Ave, El Paso TX 79905, USA, Phone: 9155456560, e-mail: hana.teissler@ ttuhsc.edu
UK National Health Service. ${ }^{1}$ Use of ultrasound guidance is a common practice for placement of peripheral nerve blocks worldwide, increasing their safety, ease of performance and decreasing complications. Ultrasound application in performing neuraxial blocks, epidural and spinal blocks for obstetric anesthesia and other surgeries is lagging behind, despite spinal and epidural anesthesia being the absolutely most widely used regional anesthetic techniques in current obstetrical anesthesia. This article will concentrate on the use of ultrasound in obstetrical anesthesia, and will discuss clinical evidence and methods of acquiring necessary skills.

Epidural needle insertion and catheter placement is historically a blind technique, where the epidural space is identified by palpation of anatomic landmarks and loss of resistance to saline or air technique when the needle passes through the ligamentum flavum. Palpation is inaccurate and depends on the anesthesiologist's level of experience; therefore failed blocks and complications are common. The most severe complication is development of the debilitating post-dural puncture headache (PDPH), which develops after about $50 \%$ of all accidental dural punctures. ${ }^{2}$ The incidence of accidental dural punctures is stated as between 1 and $5 \%{ }^{3,4}$ PDPH can be debilitating and distressing for the patient to the point of requiring an epidural blood patch, which increases the risk of yet another accidental puncture as well as epidural abscess and meningitis. ${ }^{5}$

The most common complication of epidural block with or without catheter insertion is a failure to achieve an adequate pain control. Rates of failed epidurals are anywhere from 1.5 to $20 \%$, depending on the experience of the anesthesiologist and/or the institution. ${ }^{6}$ Wrong estimation of specific lumbar spinal interspace is another possible complication of a blind technique. Studies have shown that anesthesiologist using the conventional palpation technique frequently estimates the specific lumbar interspace more caudally than visualized with ultrasound..$^{7-10}$ This can lead to more frequent spinal cord trauma and possibility of permanent neurological deficit, since the conus medullaris not infrequently extends lower than the L1 level. ${ }^{8}$ Repeated attempts and re-directions of the epidural needle are also causing pain and discomfort to the patient in labor and may unnecessarily delay the pain relief. 


\section{HISTORY OF THE USE OF ULTRASOUND FOR IMAGING OF THE LUMBAR SPINE}

Bogin and Stulin were the first to describe ultrasound (US) facilitated imaging of the lumbar spine and the use of ultrasound for lumbar puncture in $1971 .{ }^{11}$ In 1981, Cork RC et al described the use of US to localize the lumbar epidural space. They were first to define the basic components of US sonoanatomy: ligamentum flavum, spinal canal, laminae and vertebral bodies. ${ }^{12}$ In 1984 Currie JM described the US guided measurement of the distance from the skin to the epidural space. ${ }^{13}$ His work was the basis for the use of US guidance to facilitate neuraxial blockade for labor and delivery analgesia. The method is commonly used for preprocedure scanning of obese or otherwise anatomically challenging patients to assess the depth of the epidural space. $^{13}$

This study was followed in 1992 by Wallace DH who used indirect ultrasonographic guidance for epidural anesthesia in pregnant patients. ${ }^{14}$ This was the basis of today 'off-line' ultrasound use for neuraxial blocks in obstetric anesthesia. In the years 2001 to 2004 total of 11 studies about sonography use for neuraxial blocks were authored by Dr Grau $\mathrm{T}$ et al who made a major progress in spinal sonography and performance of neuraxial blocks. ${ }^{15-22}$

\section{REVIEW OF THE ANATOMY OF LUMBAR SPINE}

Lumbar vertebrae have two components: the body anteriorly and the arch posteriorly. Vertebral arch is composed of spinous process, transverse processes, pedicles, lamina and superior and inferior articular processes (Fig. 1).

The vertebral (spinal) canal is formed by the spinous process and lamina posteriorly, the pedicles laterally, and the vertebral body anteriorly.

Lumbar vertebrae are aligned vertically with articular processes and facet joints on both right and left para-medially from spinous processes and anteriorly from vertebral bodies (Fig. 2). Within the vertebral canal lies the thecal sac, formed by the dura mater and arachnoid mater. The thecal sac contains the spinal cord, cauda equina and cerebrospinal fluid.

The ligamentum flavum is a dense connective tissue ligament that bridges the gaps between laminae and interlaminar spaces. The spinous processes are connected at their tips by supraspinous ligament and along their length by interspinous ligament. The epidural space lies within the spinal canal but outside the thecal sac. The classic loss of resistance technique (LOR) is based upon the distinct change felt when the epidural needle passes through the solid fibrous ligaments into the epidural space.

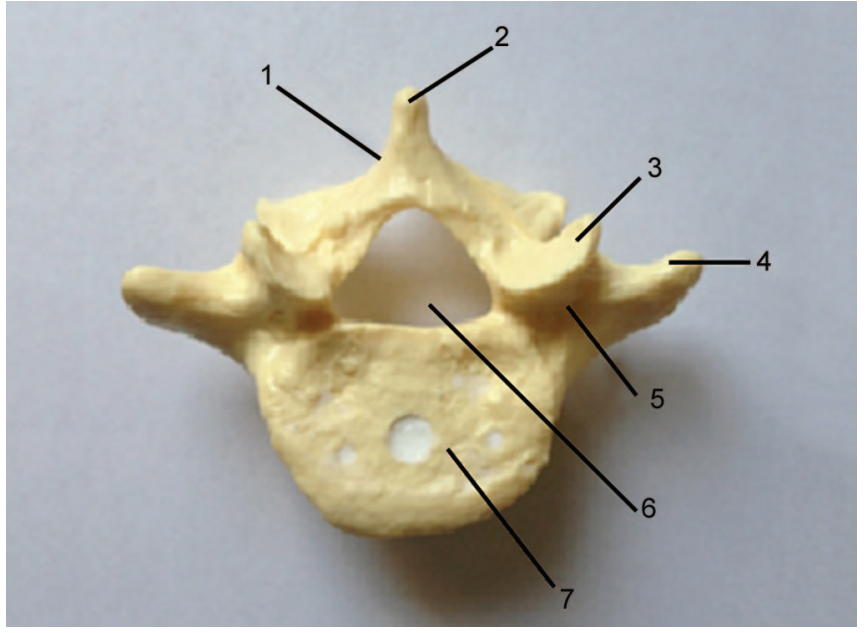

Fig. 1: Anatomy of lumbar vertebrae. Note: 1. Lamina, 2. Spinous process, 3. Articular process, 4. Transverse process, 5. Pedicle, 6. Vertebral (spinal) canal, 7. Vertebral body

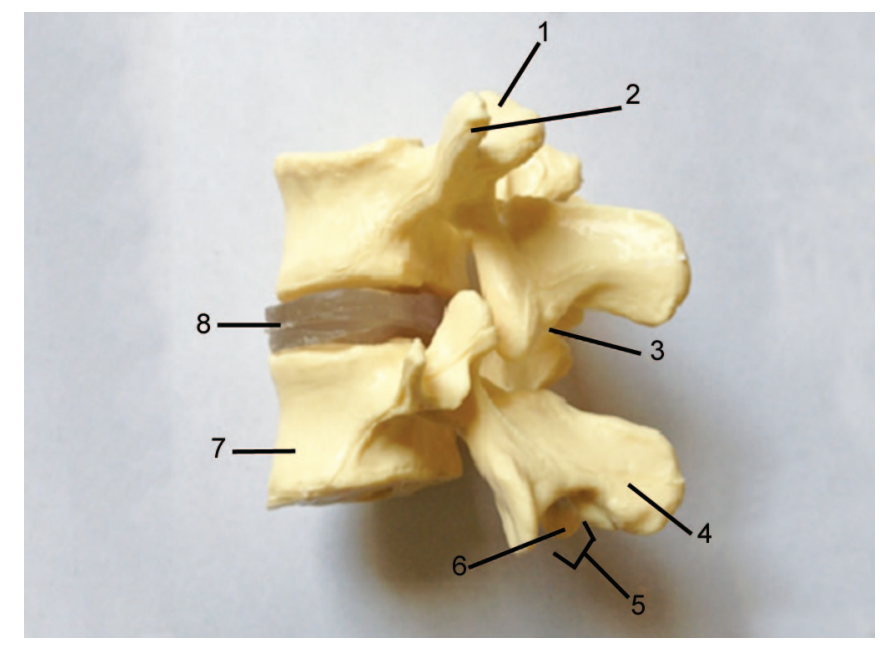

Fig. 2: Anatomy of lumbar vertebrae. Note: 1. Articular process (upper), 2. Transverse process, 3. Facet joint, 4. Spinous process, 5. Articular process (lower), 6. Facet, 7. Vertebral body, 8. Disk

Ultrasound imaging allows the anesthesiologist to visualize the structures within the vertebral canal: ligamentum flavum, epidural space and thecal sac, through the interlaminar spaces between the adjacent vertebrae that permits passage of ultrasound waves into the vertebral canal- acoustic windows. If an acoustic window between two vertebral laminae can be identified, it will likely permit the passage of a needle into the epidural or intrathecal space.

\section{PRINCIPLES OF SCANNING}

Ultrasound machine depth should be set to 7 to $8 \mathrm{~cm}$ for average size patients and 8 to $12 \mathrm{~cm}$ for most high body mass index (BMI) patients. The depth, focus and gain settings of the ultrasound machine need to be adjusted for each patient ${ }^{\text {' }} \mathrm{s}$ scan as necessary to obtain the highest quality image. ${ }^{23-28}$

Patient needs to be positioned for the scanning in the same position the epidural block will be performed; this 

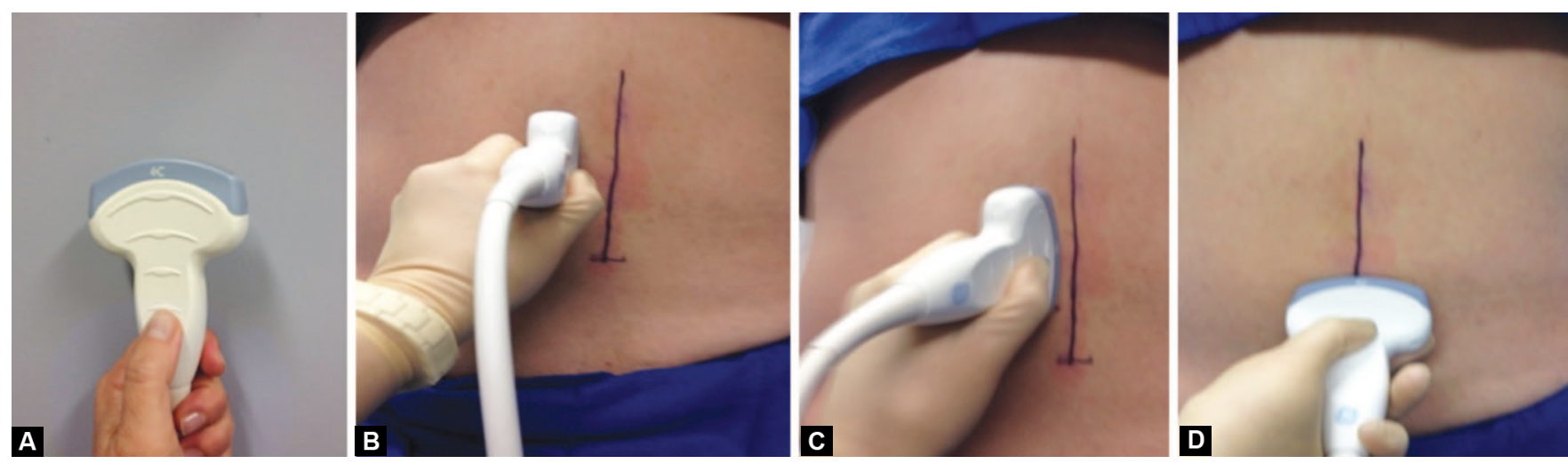

Figs 3 A to D: Typical views for sonography of the lumbar spine: (A) Curved-array, low frequency (2-5) MHz ultrasound probe is recommended, (B) paramedian sagittal view (PS), (C) paramedian sagittal oblique view (PSO) and (D) transverse view (T)

is either sitting or lateral decubitus position for obstetric analgesia. There are three basic ultrasound views for effective sonography of the lumbar spine (Fig. 3).

These planes are named after three basic anatomic planes of the human body (Fig. 4).

\section{ULTRASONOGRAPHIC VIEWS OF THE SPINE}

Pattern recognition is even more important for spinal sonoanatomy than for peripheral nerve blocks, because of the depth of the structures and limited acoustic windows which make visualization and identification more difficult. For beginner in ultrasound it is important to stress the following:

- Bony structures appear white (hyperechoic)

- Connective tissues, ligaments and fascias are also white (hyperechoic)

- Because of low acoustic impedance fluid and fat appear dark (hypoechoic).

It is very important to adopt and develop a systematic approach to scanning, using standard set of views. Systematic assessment facilitates the learning of pattern recognition and increased the overall efficiency of ultrasound guided neuraxial blockade. ${ }^{28-34}$ Here, we present the technique described by Chin et al. ${ }^{28,34}$

1. Prepare the equipment:
A. Ultrasound machine, curved array low frequency probe $(2-5 \mathrm{MHz})$
B. Marking pen
C. Ultrasound gel
D. Towels or gauze
E. Gloves

2. Position the patient in a sitting position (lateral is possible as well). Place the probe in a transverse position to the long axis of the spine at the middle of the patient's lower back - approximately at the intercristal (Touffier line), L3-L4.

3. Optimize the image by adjusting the:
A. Depth

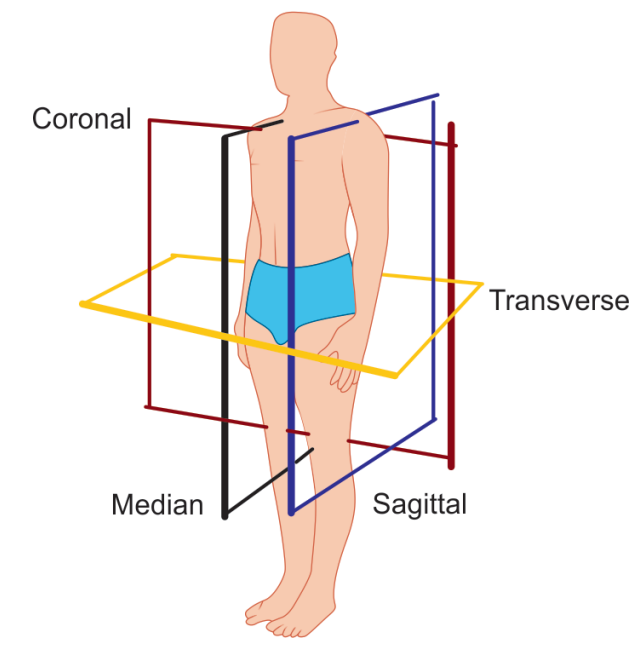

Fig. 4: Anatomic planes of the human body: sagittal, transverse and coronal. Median or mid-sagittal plane illustrates plane running through the midline
B. Frequency
C. Focus
D. Gain and Time-gain compensation (TGC)

4. Mark the midline: Probe is aligned strictly transversely to the spine structures-RT and LT sides are mirror images from the center of the probe. Sliding the probe cephalad and or caudad direction, alternating Spinous Transverse Process and Transverse Interspinous views, mark the midline over several interspaces (Figs 5 and 6).

5. Identify the lumbosacral junction and intervertebral levels: Obtain the parasagittal transverse process view (Fig. 7) by placing the probe parasagittaly about 3 to $4 \mathrm{~cm}$ from the midline. Finger-like acoustic shadows of the transverse processes or 'trident sign' will be visible. Slide probe medially toward the midline to obtain the parasagittal articular process view (camel humps) - line of hyperechoic facet joints—vertebrae connected by superior and inferior articular processes (Fig. 8). Identify the short lamina of L4/L5 (L5 lamina), slide the probe caudally, until the continuous white 


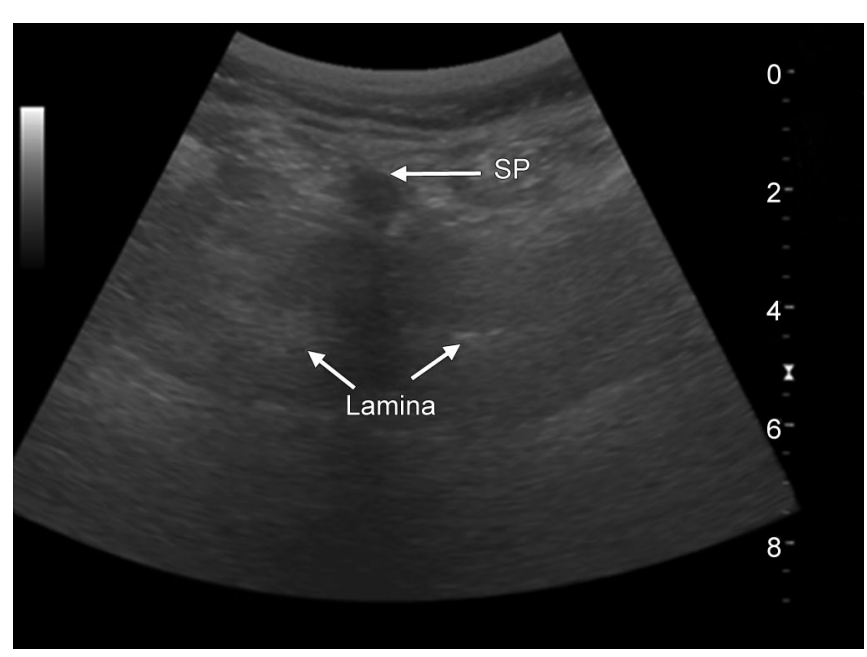

Fig. 5: Transverse spinous process view (SP)

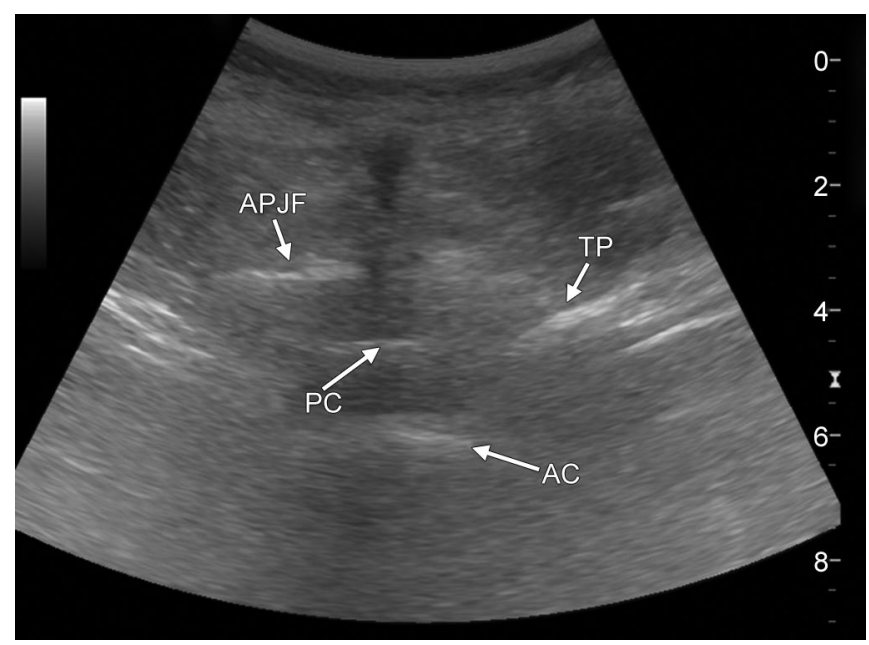

Fig. 6: Transverse interspinous view. TP-transverse process, APFJ—articular process/facet joints, PC—posterior complexligamentum flavum, epidural space and posterior dura, $\mathrm{AC}$-anterior complex-the anterior dura, posterior longitudinal ligament, posterior aspect of the vertebral body or the intervertebral disk

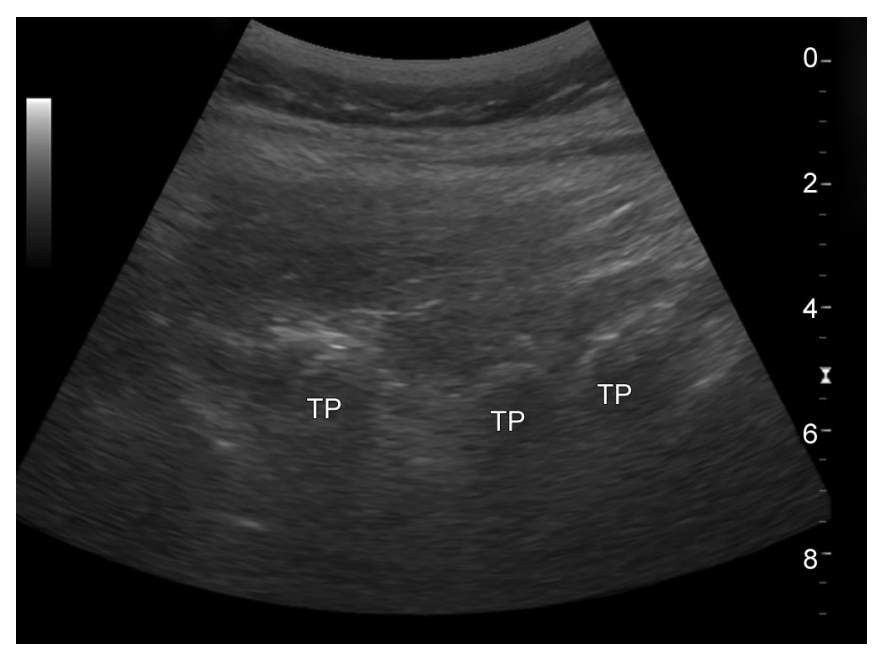

Fig. 7: Paramedian sagittal transverse process view

(hyperechoic) line of sacrum is visible. Slide the probe in a cephalad direction, centering on each lamina and marking it - the lamina/interspace will correspond to

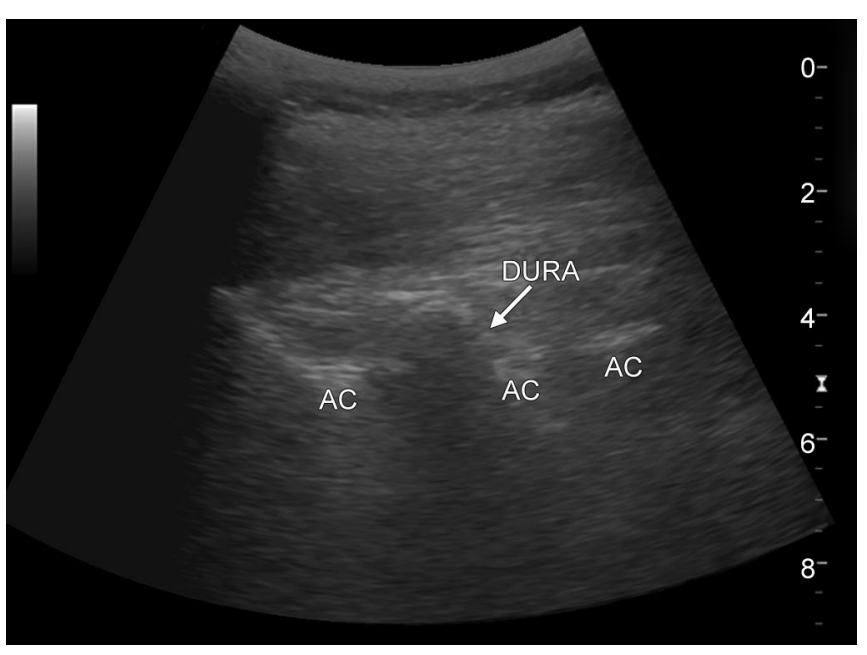

Fig. 8: Paramedian sagittal oblique view

the center of the long side of the probe. This is called 'counting up' approach. Mark the L1-L5 levels.

6. Estimate the required needle direction: The probe is rotated transversely at the desired level (e.g. L4-5 or L3-4) and transverse laminar view is obtained. The estimated best needle insertion angle or direction is identified by optimizing the image - tilting the probe in slight cephalad or caudad directions until the best view of anterior AC and posterior PC complexes is obtained.

7. Estimate the depth from the skin to the epidural space/ dura: Anterior complex, or AC, since the dura and epidural space are visualized as a single hyperechoic line. Use the ultrasound calipers to measure the distance. The true depth will differ slightly depending on how much pressure on the ultrasound probe is used for scanning.

8. Mark the optimal needle insertion point: This is best done by marking all four midpoints of the long and short edges of the probe. Put the probe aside. The optimal needle insertion point is where the lines intersect.

9. Re-apply the probe and check that you have a good view of the anterior complex from the marked insertion point. Put the probe aside.

10. Use the marked insertion point, estimated angle of insertion and estimated depth to place an epidural catheter under sterile condition.

This technique is proposed for the ultrasound guided epidural catheter placement, or preprocedure scan; so far, the most widely used technique, requiring only one provider. The placement of the catheter under a real time ultrasound is technically difficult, and usually two providers with advanced skills are required. It is best done from the Parasagittal Oblique View, when the probe is placed in a parasagittal articular view and then tilted slightly in medial direction, until acceptable image of AC and PC is obtained. From 2005 to 2010 a pre-loaded epidural syringe 'Episure 
AutoDetect LOR Syringe' (Indigo Orb) was available on US market. This needle allowed one anesthesiologist to hold the probe in one hand and the syringe in another. The syringe was spring loaded and able to identify the loss of resistance when the tip of the needle reached the epidural space. Studies to compare the Episure AutoDetect syringe with the classic glass syringe for identification of the epidural space in parturients brought mixed results. ${ }^{35,36}$ The Episure AutoDetect syringes are currently not on the US market as of July 2013.

\section{ADVANTAGES AND DISADVANTAGES OF ULTRASOUND GUIDANCE IN NEURAXIAL BLOCKS FOR OBSTETRIC ANESTHESIA}

A literature search was performed in PubMed database to review studies for the advantages and disadvantages of the US guided neuraxial blocks specifically in obstetric anesthesia. The search was limited to studies conducted from 1971 until the present on human subjects 18 years and older. Search terms included: epidural or neuraxial, ultrasound, ultrasonography, ultrasonographic and spinal sonoanatomy. During the period from 2005 to 2010, there has been an increasing number of both anesthesia and emergency medicine publications describing investigation and practical use of spinal sonography for the ease and better accuracy of neuraxial procedures. Also, ultrasound equipment both improved technically and became more affordable and available in most developed countries. In 2008 The National Institute for Health and Clinical Excellence (NICE) of UK issued guidelines on ultrasound-guided neuraxial - epidural and spinal procedures for both obstetric and nonobstetric anesthesia. ${ }^{1}$ Ultrasound machines remained too expensive, less mobile and not commonly available until 2009 to 2010 . This might reflect a small number of publications and only few case reports published before 2008. ${ }^{15-24}$ The reports focused on the advantages of the use of spinal sonography to facilitate difficult or presumed difficult epidural catheters' placement in morbidly obese patients, patients with significant scoliosis and patients with history of previous lumbar spine surgery.

Ultrasound guided regional anesthesia has since become a standard for all anesthesiology residencies. Teaching of US guided procedures to anesthesiology residents has led to increased number of studies and articles on efficacy of the use of US in anesthesiology. Several studies were published on the benefits, decreased complication rates and decrease in time to perform labor epidural placements in training institutions. ${ }^{25,26}$ Despite this widespread use of ultrasound in anesthesiology there are some studies pointing out the disadvantages of the use of ultrasound in obstetric anesthesia, mainly indicating increased cost. ${ }^{33}$ Cost of ultrasound machine and need for two providers for real time placement of epidural catheters are main limitations of the US guided technique. Placement of epidural catheter facilitated by US requires advanced training of an anesthesiologist, since there is a long learning curve associated with lumbar ultrasound. ${ }^{33}$ There is also a cost of the medical fee, CPT code 76942 paid by insurance companies for the use of ultrasound in this setting. This cost is eventually passed onto the patients.

Spinal ultrasound is not easy to learn, requires advanced training and instruction. There is a long learning curve associated with lumbar spine ultrasound and the teaching methods are not standardized and vary extensively from institution to institution and between the countries. The deficiencies in teaching and training are more pronounced in the clinical setting of obstetric anesthesia, when patients are in labor and time is of essence. The literature reviewed for advantages and disadvantages of ultrasound guided neraxial blocks in obstetric anesthesia are summarized in Table 1.

Advantages of the use of ultrasound for epidural placement are the following:

1. Preprocedure or 'off-line' ultrasound helps visualize the anatomy, select the correct intervertebral space, measure the depth from skin to the epidural space and help to plan the insertion angle for needle trajectory.

2. Real time 'on-line' ultrasound allows visualization of the epidural needle placement.

3. Both preprocedure and real time ultrasound visualization of the epidural space are helpful in aiding an epidural catheter placement or subarachnoidal block in a morbidly obese patient and patient with an altered anatomy, mainly previous lumbar spine surgeries and kyphoscoliosis.

4. Visualization of epidural space with ultrasound is a valuable teaching tool for residents and shortens the learning curve and improves the success rate.

5. Improved block success - reduces rates of failed epidural placement resulting in inadequate analgesia, lower rate of postdural puncture spinal headaches (PDPH).

Disadvantages of the use of ultrasound for epidural placement include the following:

1. Need of expensive equipment

2. Lack of trained providers in both EU and US

3. Two providers necessary for real-time ultrasound guided epidural catheter placement

4. One-provider real time US technique is currently not available (Autodetect epidural needles (Episure) are not available on the market).

These are multiple drawbacks to broader use of spinal sonography worldwide. The technique requires ultrasound 
The Use of Ultrasonography for the Guidance of Epidural Analgesia in Obstetric Anesthesia

Table 1: Advantages and disadvantages of ultrasound guided neraxial blocks in obstetric anesthesia

\begin{tabular}{|c|c|c|c|c|}
\hline Author/Year & Study objectives & Methodology & Findings/Results & Relevant evidence \\
\hline Currie $\mathrm{JM}^{13}$ (1984) & $\begin{array}{l}\text { Tested the accuracy } \\
\text { of US measurement of } \\
\text { the depth of extradural } \\
\text { space }\end{array}$ & $\begin{array}{l}\text { Single-arm prospective } \\
\text { cohort study; } 75 \text { patients } \\
\text { requesting extradural } \\
\text { analgesia; US blinded } \\
\text { by second operator; } \\
\text { correlation coefficient }\end{array}$ & $\begin{array}{l}\text { Provided accurate } \\
\text { readings of the depth of } \\
\text { the extradural space in } \\
43 \text { cases }\end{array}$ & $\begin{array}{l}\text { Initial evidence that } \\
\text { US benefits/facilitates } \\
\text { extradural block }\end{array}$ \\
\hline Wallace et $\mathrm{al}^{14}$ (1992) & $\begin{array}{l}\text { Use of epidural } \\
\text { anesthesia using } \\
\text { sonographic guidance } \\
\text { to locate epidural space } \\
\text { correctly }\end{array}$ & $\begin{array}{l}\text { Single-arm prospective } \\
\text { cohort study; } 36 \text { obese } \\
\text { patients scheduled for } \\
\text { elective repeat cesarean } \\
\text { delivery; linear regression } \\
\text { analysis }\end{array}$ & $\begin{array}{l}\text { Satisfactory epidural } \\
\text { anesthesia was } \\
\text { accomplished in all } \\
\text { obese patients with } \\
\text { indirect sonographic } \\
\text { guidance }\end{array}$ & $\begin{array}{l}\text { Needle depth could be } \\
\text { predicted with US in } \\
\text { difficult cases }\end{array}$ \\
\hline Grau et al ${ }^{15}(2001)$ & $\begin{array}{l}\text { Evaluated the visibility } \\
\text { of all anatomical } \\
\text { structures and } \\
\text { compared the distances } \\
\text { measured by US and } \\
\text { during puncture }\end{array}$ & $\begin{array}{l}\text { Prospective study; } \\
100 \text { pregnant women, } \\
\text { admitted for childbirth and } \\
\text { undergoing epidural block; } \\
\text { correlation coefficient }\end{array}$ & $\begin{array}{l}\text { Correlation between } \\
\text { distances measured } \\
\text { by ultrasound and } \\
\text { puncture needle was } \\
\text { high }(r=0.79) ; \text { patient } \\
\text { acceptance of the } \\
\text { procedure was very } \\
\text { good }\end{array}$ & $\begin{array}{l}\text { Show ultrasound ability } \\
\text { to determine site and } \\
\text { direction of epidural } \\
\text { puncture }\end{array}$ \\
\hline Grau et al ${ }^{16} 2001$ & $\begin{array}{l}\text { Investigated whether } \\
\text { prepuncture US } \\
\text { examination of the } \\
\text { spinal anatomy is } \\
\text { beneficial in expected } \\
\text { cases of difficult } \\
\text { epidural anesthesia }\end{array}$ & $\begin{array}{l}\text { Prospective randomized } \\
\text { study; } 72 \text { patients with } \\
\text { abnormal anatomical } \\
\text { conditions scheduled for } \\
\text { epidural anesthesia, } 36 \\
\text { per group; Chi-square test, } \\
\text { Bland-Altman analysis }\end{array}$ & $\begin{array}{l}\text { In US group results } \\
\text { were optimal skin } \\
\text { puncture site, ideal } \\
\text { direction of needle } \\
\text { advancement and } \\
\text { skin-to-epidural space } \\
\text { distance }\end{array}$ & $\begin{array}{l}\text { Use of ultrasound } \\
\text { facilitates epidural } \\
\text { anesthesia by pre- } \\
\text { puncture findings of } \\
\text { spinal anatomy in difficult } \\
\text { cases }\end{array}$ \\
\hline Grau et al ${ }^{17}$ (2001) & $\begin{array}{l}\text { Investigated the } \\
\text { influence to the tissue } \\
\text { alterations of pregnancy } \\
\text { on epidural technique }\end{array}$ & $\begin{array}{l}\text { Prospective cohort study; } \\
60 \text { patients receiving } \\
\text { epidural block for } \\
\text { conventional or cesarean } \\
\text { delivery; Chi-square test, } \\
\text { student's t-test }\end{array}$ & $\begin{array}{l}\text { US enabled assessment } \\
\text { of landmarks for } \\
\text { puncture }\end{array}$ & $\begin{array}{l}\text { Benefit of ultrasound } \\
\text { is to identify important } \\
\text { structures for epidural } \\
\text { anesthesia }\end{array}$ \\
\hline Grau et $\mathrm{al}^{6}$ (2001) & $\begin{array}{l}\text { Evaluated usefulness } \\
\text { of US in facilitating } \\
\text { localization of the } \\
\text { epidural space }\end{array}$ & $\begin{array}{l}\text { Case control study; } \\
80 \text { patients with cesarean } \\
\text { delivery, US }(n=40) \text {, } \\
\text { control group ( } n=40) \text {; US } \\
\text { measured epidural space } \\
\text { by single operator; Chi- } \\
\text { square test and student's } \\
\text { t-test }\end{array}$ & $\begin{array}{l}\text { Bony landmarks, } \\
\text { including the spinous } \\
\text { and transverse } \\
\text { processes, and facet } \\
\text { joints can easily be } \\
\text { identified by US }\end{array}$ & $\begin{array}{l}\text { Use of US is beneficial } \\
\text { for localization of } \\
\text { epidural space. There } \\
\text { is significant reduction } \\
\text { in puncture attempts. } \\
\text { Preparation time was } \\
\text { not significantly altered. } \\
\text { US of the epidural } \\
\text { space does not cause } \\
\text { discomfort }\end{array}$ \\
\hline Grau et al ${ }^{18}(2001)$ & $\begin{array}{l}\text { Assessment of } 3 \\
\text { ultrasound planes } \\
\text { (transverse, median } \\
\text { and paramedian) for } \\
\text { assessment of the } \\
\text { visibility of epidural } \\
\text { space }\end{array}$ & $\begin{array}{l}\text { Case control study; } \\
60 \text { patients and } \\
40 \text { healthy volunteers; } \\
\text { US measurement of the } \\
\text { epidural space and its } \\
\text { surrounding structures; } \\
\text { student's t-test }\end{array}$ & $\begin{array}{l}\text { In the paramedian } \\
\text { plane, the permeable } \\
\text { window was larger } \\
(p<0.001) \text { than in } \\
\text { the median approach. } \\
\text { The visibility of the } \\
\text { ligamentum flavum } \\
(p<0.0001) \text {, dura mater } \\
(p<0.0001) \text { and cauda } \\
\text { equina }(p<0.0001) \text { was } \\
\text { significantly higher }\end{array}$ & $\begin{array}{l}\text { The longitudinal } \\
\text { paramedian plane } \\
\text { provides information } \\
\text { about the epidural } \\
\text { space depth in excellent } \\
\text { imaging quality }\end{array}$ \\
\hline Grau et al ${ }^{19}(2001)$ & $\begin{array}{l}\text { Evaluation of the } \\
\text { usefulness of color } \\
\text { Doppler assessment } \\
\text { in the screening of the } \\
\text { trajectory of the epidural } \\
\text { needle }\end{array}$ & $\begin{array}{l}\text { Case control study; } 20 \\
\text { volunteers; ultrasound } \\
\text { examination of L3/4 } \\
\text { interspace; vascular } \\
\text { structures were identified } \\
\text { by pulsation (B mode) and } \\
\text { blood flow (Doppler) }\end{array}$ & $\begin{array}{l}\text { Vessel detection was } \\
\text { possible in } 50 \% \text { of the } \\
\text { B-mode images and in } \\
\text { all of the } 4-\mathrm{MHz} \text { Doppler } \\
\text { images. Vessels were } \\
\text { perceptible from a } \\
\text { diameter of } 0.5 \mathrm{~mm} / \\
\text { veins were the } \\
\text { predominantly visible } \\
\text { structures }\end{array}$ & $\begin{array}{l}\text { Prepuncture Doppler } \\
\text { imaging can provide the } \\
\text { anesthesiologist with } \\
\text { information regarding } \\
\text { the position of vessels } \\
\text { in the needle trajectory. } \\
\text { This might help to reduce } \\
\text { complications in regional } \\
\text { anesthesia }\end{array}$ \\
\hline
\end{tabular}




\begin{tabular}{|c|c|c|c|c|}
\hline Author/Year & Study objectives & Methodology & Findings/results & Relevant evidence \\
\hline Grau et $\mathrm{al}^{6} 2002$ & $\begin{array}{l}\text { Assessment of the } \\
\text { clinical use of US for } \\
\text { localization of the } \\
\text { epidural anesthesia }\end{array}$ & $\begin{array}{l}\text { Randomized prospective } \\
\text { study; } 300 \text { patients, in } \\
\text { each group }(n=150) 85 \\
\text { conventional delivery and } \\
65 \text { cesarean sections; } \\
\text { Chi-square test, } \\
\text { Bland-Altman analysis }\end{array}$ & $\begin{array}{l}\text { US for structure } \\
\text { detection results in } \\
\text { reduced number of } \\
\text { puncture attempts, less } \\
\text { side effects, higher } \\
\text { patient satisfaction }\end{array}$ & $\begin{array}{l}\text { The clinical use of } \\
\text { ultrasound for epidural } \\
\text { catheter placement } \\
\text { may improve regional } \\
\text { anesthesia. The use of } \\
\text { ultrasound resulted in } \\
\text { superior quality in all } \\
\text { measured endpoints }\end{array}$ \\
\hline Grau et al ${ }^{21}$ (2003) & $\begin{array}{l}\text { Evaluation of the } \\
\text { teaching possibilities } \\
\text { of US as a diagnostic } \\
\text { approach to the epidural } \\
\text { region }\end{array}$ & $\begin{array}{l}\text { Prospective, randomized, } \\
\text { nonblinded study; two } \\
\text { groups of five residents } \\
\text { performing first } 60 \\
\text { epidurals; Chi-square test, } \\
\text { student t-test }\end{array}$ & $\begin{array}{l}\text { Using US the learning } \\
\text { curves started at a } \\
\text { mean level of } 86 \% \\
\text { and rose up to a mean } \\
\text { success rate of } 94 \% \\
\text { after } 60 \text { epidurals. } \\
\text { In comparison, the } \\
\text { learning curve without } \\
\text { US started at } 60 \% \text { and } \\
\text { reached a maximum of } \\
84 \%\end{array}$ & $\begin{array}{l}\text { Demonstrates the value } \\
\text { of ultrasound imaging for } \\
\text { teaching and learning } \\
\text { obstetric epidural } \\
\text { anesthesia }\end{array}$ \\
\hline Grau et al ${ }^{22}$ (2004) & $\begin{array}{l}\text { Evaluation of real-time } \\
\text { US control for epidural } \\
\text { anesthesia }\end{array}$ & $\begin{array}{l}\text { Prospective randomized } \\
\text { study; } 30 \text { patients } \\
\text { scheduled for cesarean } \\
\text { section, } 10 \text {-control, } \\
10 \text {-online imaging, } \\
10 \text {-offline imaging }\end{array}$ & $\begin{array}{l}\text { Real-time ultrasonic } \\
\text { scanning of the lumbar } \\
\text { spine provides an } \\
\text { accurate reading of the } \\
\text { location of the needle } \\
\text { tip and facilitates } \\
\text { the performance of } \\
\text { combined spinal- } \\
\text { epidural anesthesia }\end{array}$ & $\begin{array}{l}\text { Use of ultrasound is } \\
\text { effective in identifying } \\
\text { epidural structures }\end{array}$ \\
\hline Vallejo et $\mathrm{al}^{31}$ (2010) & $\begin{array}{l}\text { Evaluation of the } \\
\text { measurements of the } \\
\text { epidural space depth }\end{array}$ & $\begin{array}{l}\text { Prospective, randomized, } \\
\text { nonblinded study; } 379 \\
\text { patients requesting labor } \\
\text { epidural analgesia, US } \\
\text { group = } 189 \text { and control } \\
\text { group = } 181 \text {; Pearson's } \\
\text { correlation coefficients, } \\
\text { multivariate linear } \\
\text { regression }\end{array}$ & $\begin{array}{l}\text { US planes have high } \\
\text { correlation with actual } \\
\text { clinical depth to the } \\
\text { epidural space; US } \\
\text { was successful in } 186 \\
\text { patients vs } 171 \text { with no } \\
\text { US respectively }\end{array}$ & $\begin{array}{l}\text { Ultrasound for the } \\
\text { guidance of epidural } \\
\text { analgesia has higher } \\
\text { success rate }\end{array}$ \\
\hline Gambling DR ${ }^{32}$ (2011) & $\begin{array}{l}\text { Analysis of the literature } \\
\text { on impact of ultrasound } \\
\text { use on ease and } \\
\text { comfort of epidural } \\
\text { anesthesia and success } \\
\text { rate }\end{array}$ & Review article & $\begin{array}{l}\text { Cost-beneficial, } \\
\text { decreased time, } \\
\text { feasibility of use, } \\
\text { effectiveness of lumbar } \\
\text { US }\end{array}$ & $\begin{array}{l}\text { Risk analysis for lumbar } \\
\text { ultrasound during } \\
\text { pregnancy should be } \\
\text { performed. The issue } \\
\text { of ultrasound biosafety } \\
\text { needs to be considered } \\
\text { before use of US in } \\
\text { pregnant patients }\end{array}$ \\
\hline
\end{tabular}

equipment, which is expensive and not available in developing countries, not even in all US hospitals with obstetric wards. The use of ultrasound for visualization of spinal anatomy requires an experienced anesthesiologist with special training in ultrasound. Until a safe and costbeneficial technique will be developed for only one provider to be able to perform both scanning and needle placement in 'real time', the technique requires two providers, which is economically and practically burdensome for most but largest teaching institutions.

\section{CONCLUSION}

At this time ultrasound guided technique of epidural and spinal blocks for obstetric patients should not replace the traditional landmark and palpation technique of neuraxial anesthesia for all patients. The traditional technique is easy, economically advantageous and has minimal risks and complications when performed by well-trained providers. Ultrasound guidance performed as preprocedure scanning is invaluable in facilitating placement of difficult epidural and spinal blocks, such as in morbidly obese patients, patients with severe scoliosis and patients with history of previous spinal surgeries and instrumentation. Spinal sonography is also an invaluable tool in teaching anesthesiology residents the basic, as well as complicated and altered spinal sonoanatomy. More work needs to be done in developing a standardized teaching approach for residents and practitioners to increase the use of ultrasound guidance 
for performance of neuraxial blocks for obstetric anesthesia, as well as increase of its efficacy and more widespread use.

\section{REFERENCES}

1. National Institute for Health and Clinical Excellence. Ultrasound-guided catheterisation of the epidural space. London: National Institute for Health and Clinical Excellence 2008; ISBN 1-84629-583-1. Available at: http://www.nice.org.uk/nicemedia/ pdf/ipg249guidance.pdf (Accessed on August 23, 2013).

2. Choi PT, Galinski SE, Takeuchi L, Lucas S, Tamayo C, Jadad AR. PDPH is a common complications of neuraxial blockade in parturients: a meta-analysis of obstetrical studies. Can J Anesth 2003; 50(5):460-469.

3. Pan PH, Bogard TD, Owen MD. Incidence and characteristics of failures in obstetric neuraxial analgesia and anesthesia: a retrospective analysis of 19,259 deliveries. Int J Obstet Anesth 2004;13(4):227-223.

4. Carvalho JC. Ultrasound facilitated epidurals and spinals in obstetrics. Anesthesiol Clin 2008; 26(1):145-158.

5. Baraz R, Collins RE. The management of accidental dural puncture during labour analgesia: a survey of UK practice. Anaesthesia 2005;60(7):673-679.

6. Grau T, Leipold RW, Conradi R, Martin E, Motsch J. Efficacy of ultrasound imaging in obstetric epidural anesthesia. J Clin Anesth 2002;14(3):169-175.

7. Broadbent CR. Ability of Anaesthetists to identify a marked lumbar interspace. Anaesthesia 2000; 56(11); 1122-1126.

8. Reynolds F. Damage to the conus medullaris following spinal anaesthesia. Anaesthesia 2001;56(3):238-247.

9. Broadbent CR, Maxwell WB, Ferrie R, et al. Ability of anaesthetists to identify a marked lumbar interspace. Anaesthesia 2000; 55:1122-1126.

10. Furness G, Reilly MP, Kuchi S. An evaluation of ultrasound imaging for identification of lumbar intervertebral level. Anaesthesia 2002;57:277-283.

11. Bogin IN, Stulin ID. Application of the method of two-dimensional echospondylography for determining landmarks in lumbar punctures. Zh Nevropatol Psikhiatr Im SS Korsakova 1971; 71(12):1810-1811.

12. Cork RC, Kryc JJ, Vaughan RW. Ultrasonic localization of the lumbar epidural space. Anesthesiology 1980;52:513-516.

13. Currie JM. Measurement of the depth of the extradural space using ultrasound. Br J Anaesth 1984;56:345-347.

14. Wallace DH, Currie JM, Gilstrap LC, Santos R. Indirect sonographic guidance in obese pregnant patients. Regional Anesth 1992;17:233-236.

15. Grau T, Leipold RW, Conradi R, Martin E, Motsch J. Ultrasonography and peridural anesthesia. Technical possibilities and limitations of ultrasonic examination of the epidural space. Anaesthestist 2001;50:94-101.

16. Grau T, Leipold RW, Conradi R, Martin E. Ultrasound control for presumed difficult epidural puncture. Acta Anaesthesiol Scand 2001;45:766-771.

17. Grau T, Leipold RW, Conradi R, Martin E, Motsch J. Ultrasound imaging facilitates localization of the of the epidural space during combined spinal and epidural anesthesia. Reg Anest Pain Med 2001;26:64-67.
18. Grau T, Leipold RW, Horter J, Martin E, Motsch J. Paramedian access to the epidural space: The optimum window for ultrasound imaging. J Clin Anesth 2001;13:213-217.

19. Grau T, Leipold RW Horter J, Martin E, Motsch J. Colour Doppler imaging of the interspinous and epidural space. Eur J Anaesthesiol 2001;18:706-712.

20. Grau T, Conradi R, Martin E, Motsch J. Ultrasound and local anaesthesia. Part III: Ultrasound and neuroaxial local anaesthesia. Anaesthestist 2003; 52:68-73.

21. Grau T, Bartusseck E, Conradi R, Martin E, Motsch J. Ultrasound imaging improves learning curves in obstetric epidural anesthesia: a preliminary study. Can J Anesth 2003;50(10): 1047-1050.

22. Grau T, Leipold RW, Fatehi S, Martin E, Motsch J. Real- time ultrasonic observation of combined spinal-epidural anaesthesia. Eur J Anaesthesiol 2004; 86:798-804.

23. McLeod A, Roche A, Fennelly M. Case series: Ultrasonography may assist epidural insertion in scoliosis patients. Can J Anesth 2005;52:717-720.

24. Peng PW, Rofaeel A. Using ultrasound in case of difficult epidural needle placement. Can J Anesth 2006;53:325-326.

25. Yamauchi M, Honma E, Mimura M, Yamamoto H, Takahashi E, Namiki A. Identification of the lumbar intervertebral level using ultrasound imaging in postlaminectomy patient. J Anesth 2006;20:321-323.

26. Vallejo MC, Phelps AL, Singh S, Orebaugh SL, Sah N. Ultrasound decrease the failed labor epidural rate in resident trainees. J Obstetric Anesthesia 2010;19:373-378.

27. Coubert C, Hinova A, Fernando R. Update on modern neuraxial analgesia in labour: a review of the literature of the last 5 years. Anaesthesia 2011;66:191-212.

28. Chin KJ, Karmakar MK, Peng P. Ultrasonography of the Adult Thoracic and Lumbar Spine for the Central Neuraxial Blockade. Anesthesiology 2011;114:1459-1485.

29. Guglielminotti J. Development and evaluation of a score to predict difficult epidural placement during labor. RAPM 2013; 38(3):233-238.

30. Shaikh F, Brzezinski J, Alexander S, Arzola C, Carvalho JCA, Beyene J, Sung L. Ultrasound imaging for lumbar punctures and epidural catheterizations: systematic review and meta-analysis. BMJ 2013;346:f172.

31. Vallejo, MC, Singh S, Chelly JE. Ultrasound for the guidance of epidural analgesia. Anesthesiology News Special Edition 2009; 19-24.

32. Gambling DR. Lumbar ultrasound: useful gadget or timeconsuming gimmick? IJ of Obstetric Anesthesia 2011;20: 318-320.

33. Margarido CB, Arzola C, Balki M, Carvalho JC. Anesthesiologists' learning curves for ultrasound of the lumbar spine. Can J Anesth 2010;57:120-126.

34. Chin A, Crooke B, Frederickson M. Available at: www. ultrasoundblocks.com (Accessed on August 23, 2013).

35. Habib AS, George RB, Allen TK, Olufolabi AJ. A pilot study to compare the Episure Autodetect syringe with the glass syringe for identification of the epidural space in parturients. International Anesthesia Research Society 2008;106(2):541-543.

36. Paech MJ, Muchatuta NA, Griffiths JD, Nathan EA. The EpiSure loss-of-esistance syringe. Anaesthesia and Intensive care 2011; 39(5):976-977. 